Correspondence

Yoshihiko Sako

sako@kais.kyoto-u.ac.jp

\title{
Marinithermus hydrothermalis gen. nov., sp. nov., a strictly aerobic, thermophilic bacterium from a deep-sea hydrothermal vent chimney
}

\author{
Yoshihiko Sako, ${ }^{1}$ Satoshi Nakagawa, ${ }^{1}$ Ken Takai $^{2}$ and Koki Horikoshi ${ }^{2}$ \\ ${ }^{1}$ Laboratory of Marine Microbiology, Graduate School of Agriculture, Kyoto University, Kyoto \\ 606-8502, Japan \\ ${ }^{2}$ Subground Animalcules Retrieval (SUGAR) Project, Frontier Research System for \\ Extremophiles, Japan Marine Science \& Technology Center, 2-15 Natsushima-cho, Yokosuka \\ 237-0061, Japan
}

\begin{abstract}
A novel thermophilic marine bacterium, designated strain $\mathrm{T}^{\top}$, was isolated from a deep-sea hydrothermal vent chimney sample collected from the Suiyo Seamount in the Izu-Bonin Arc, Japan, at a depth of $1385 \mathrm{~m}$. Cells of strain $\mathrm{T}^{\top}{ }^{\top}$ were rod-shaped, occurring in pairs or filamentous, and stained Gram-negative. Growth was observed between 50.0 and $72.5^{\circ} \mathrm{C}$ (optimum $67.5^{\circ} \mathrm{C}$; 30 min doubling time) and at $\mathrm{pH} 6 \cdot 25-7 \cdot 75$ (optimum $\mathrm{pH} 7 \cdot 00$ ). The isolate absolutely required $\mathrm{NaCl}$, at a concentration of $0 \cdot 5-4 \cdot 5 \%$ (optimum $3 \cdot 0 \%$ ). It was a strictly aerobic heterotroph capable of growing solely on complex organic substrates such as yeast extract, tryptone and Casamino acids, utilizing glutamate, proline, serine, cellobiose, trehalose, sucrose, acetate and pyruvate as complementary substrates. The $\mathrm{G}+\mathrm{C}$ content of the genomic DNA was $68.6 \mathrm{~mol} \%$. The 16S rRNA gene sequence of the isolate was most similar to those from members of the genus Thermus, but the isolate was distantly related to them at the genus level ( $<90 \%)$. In addition, phylogenetic analysis indicated that the isolate was on a novel lineage, deeply branched prior to divergence of the genus Thermus. On the basis of phylogenetic analysis and physiological traits of the isolate, it should be described as a member of a novel genus distinct from the previously described genus Thermus. The name Marinithermus gen. nov. is proposed, with Marinithermus hydrothermalis gen. nov., sp. nov. as the type species. The type strain of $M$. hydrothermalis gen. nov., sp. nov. is strain $\mathrm{T}^{\top}{ }^{\top}$ (=JCM $\left.11576^{\top}=\mathrm{DSM} 14884^{\top}\right)$.
\end{abstract}

\section{INTRODUCTION}

A number of aerobic thermophiles have been isolated from a variety of geothermal environments such as hot springs, solfataric fields and hydrothermal vents throughout the world (Brock \& Freeze, 1969; Brock et al., 1972; Grogan et al., 1990; Huber et al., 1992; Sako et al., 1996a, b, 2001). Members of the genus Thermus are probably the most frequently isolated extremely thermophilic aerobes from terrestrial hot-water environments. Although some strains grow mixotrophically (Skirnisdottir et al., 2001), almost all strains of the genus Thermus are obligate heterotrophs that live in various terrestrial hot environments at temperatures higher than about $55^{\circ} \mathrm{C}$ and neutral to alkaline pH (Brock \& Boylen, 1973; Pask-Hughes \& Williams, 1975; Kristjánsson \& Alfredsson, 1983; Williams \& da Costa, 1992). Under anaerobic conditions, some strains of the

Published online ahead of print on 28 June 2002 as DOI 10.1099/ ijs.0.02364-0.

The DDBJ/EMBL/GenBank accession number for the 16S rDNA sequence of strain $T 1^{\top}$ is $\mathrm{AB} 079382$. genus Thermus are able to grow with $\mathrm{NO}_{3}^{-}, \mathrm{Fe}(\mathrm{III})$ and $\mathrm{S}^{0}$ as terminal electron acceptors instead of $\mathrm{O}_{2}$ (Williams \& da Costa, 1992; Sharp et al., 1995; Kieft et al., 1999).

In deep-sea hydrothermal vent environments, however, most thermophiles had been thought to be strict anaerobes until the recent discovery of facultatively aerobic thermophiles from deep-sea hydrothermal vent chimneys (Blöchl et al., 1997; Reysenbach et al., 2000a). In addition, many strictly aerobic and thermophilic bacterial strains, including Thermus thermophilus Gy1211, have been isolated from deep-sea hydrothermal vent environments in the MidAtlantic Ridge and Guaymas Basin (Marteinsson et al., 1995, 1999). These results suggest that strictly or facultatively aerobic microbial populations of thermophiles occur in relatively oxidative microhabitats of deep-sea hydrothermal vent environments and that their diversity and function in the whole microbial community have potentially been underestimated.

In this study, fully aerobic thermophilic micro-organisms were cultivated from a deep-sea hydrothermal vent chimney 
at the Suiyo Seamount in the Izu-Bonin Arc, Japan. From this hydrothermal system, various previously uncultivated bacterial and archaeal rDNA sequences were obtained by a culture-independent molecular survey (Takai \& Horikoshi, 1999), although enrichment and cultivation of aerobic thermophiles have not yet been examined. A novel, strictly aerobic thermophile was isolated from the surface layer of a black smoker chimney structure. Here, the physiological and molecular properties of the novel isolate are characterized and the potential distribution of such aerobic thermophiles in deep-sea hydrothermal vents is discussed.

\section{METHODS}

Sample collection. Samples from black smoker vents were obtained from the hydrothermal field at the Suiyo Seamount in the Izu-Bonin Arc, Japan $\left(28^{\circ} 34 \cdot 287^{\prime} \mathrm{N}, 140^{\circ} 38 \cdot 663^{\prime} \mathrm{E}\right)$, at a depth of $1385 \mathrm{~m}$ by means of the manned submersible Shinkai 2000 in a dive (dive no. 237) performed in November 2000. A bulk of chimney with a vent emission temperature of $310 \cdot 8{ }^{\circ} \mathrm{C}$ was brought to the sea surface in a sample box from the submersible and immediately subsampled into four different parts (top part of the chimney, surface layer of the chimney, inside structure and vent surface) as described by Takai et al. (2001). The chimney was mainly composed of anhydrite (top part), barite (surface layer) and pyrite and chalcopyrite (inside structure); pyrite or chalcopyrite crystals were observed at the passage of hot fluid (vent surface). Each of the subsamples (approx. $10 \mathrm{~g}$ ) was suspended in $20 \mathrm{ml}$ sterilized MJ synthetic sea water (described below) containing $0.05 \%(\mathrm{w} / \mathrm{v})$ sodium sulfide in a $100 \mathrm{ml}$ glass bottle (Schott Glaswerke) tightly sealed with a butyl rubber cap under a gas phase $100 \% \mathrm{~N}_{2}(100 \mathrm{kPa})$. These suspended portions of the subsamples were used to inoculate a series of media, including MJYPV medium (described below) on board the surface vessel.

Enrichment and purification. The enrichment was performed in screw-capped test tubes (Pyrex; $180 \times 18 \mathrm{~mm}$ ) containing $5 \mathrm{ml}$ medium with air; cultures were incubated at 70 and $85^{\circ} \mathrm{C}$. The tubes of MJYPV medium inoculated only with a subsample of surface layer became turbid after 1 day incubation at both temperatures and the other subsamples did not provide positive enrichments even after 5 days incubation at 70 and $85^{\circ} \mathrm{C}$. The enrichment cultures grown at $70{ }^{\circ} \mathrm{C}$ contained slightly motile, long rod-shaped cells, whereas those at $85{ }^{\circ} \mathrm{C}$ contained highly motile coccoids. To obtain a pure culture of long rod cells grown at $70{ }^{\circ} \mathrm{C}$, the enriched cells were streaked onto MJYPV plates hardened with $0.5 \%(\mathrm{w} / \mathrm{v})$ gelrite gellan gum (Sigma). After 1 day of incubation at $70{ }^{\circ} \mathrm{C}$, white colonies formed on the plates. Well-isolated colonies were picked and the cells were incubated in fresh liquid MJYPV medium at $70{ }^{\circ} \mathrm{C}$. To ensure purity, the streaking and isolation step was repeated at least three times for each isolate. The first pure culture was designated strain $\mathrm{T1}^{\mathrm{T}}$ and was investigated in detail.

Culture media and conditions. The isolate was routinely cultivated in MJYPV medium, which contained the following components in $11 \mathrm{MJ}$ synthetic sea water (Sako et al., 1996b): $1 \mathrm{~g}$ yeast extract (Difco), $1 \mathrm{~g}$ tryptone (Difco) and $10 \mathrm{ml}$ vitamin solution (Balch et al., 1979). To prepare MJYPV medium, $1 \mathrm{~g}$ yeast extract and $1 \mathrm{~g}$ tryptone were dissolved in $11 \mathrm{MJ}$ synthetic sea water and the $\mathrm{pH}$ of the medium was adjusted to approximately $7 \cdot 0$ with $\mathrm{NaOH}$ prior to autoclaving, unless otherwise noted. Filter-sterilized vitamin solution (Balch et al., 1979) was added after autoclaving. For testing the effects of $\mathrm{pH}$ on growth, the $\mathrm{pH}$ of MJYPV medium containing $20 \mathrm{mM}$

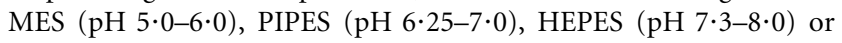
CAPSO ( $\mathrm{pH} 8 \cdot 5$ and above) was adjusted to the required value with
$\mathrm{H}_{2} \mathrm{SO}_{4}$ or $\mathrm{NaOH}$ at room temperature. The $\mathrm{pH}$ was checked after autoclaving and was axenically readjusted with $\mathrm{H}_{2} \mathrm{SO}_{4}$ or $\mathrm{NaOH}$ at room temperature if necessary. The $\mathrm{pH}$ of all media was stable during the cultivation period. $\mathrm{NaCl}$ requirements were determined with a varying concentration of $0-6 \%(\mathrm{w} / \mathrm{v}) \mathrm{NaCl}$ in $\mathrm{MJ}$ synthetic sea water.

In an attempt to examine whether the isolate was able to grow under anaerobic conditions, $\mathrm{H}_{2}+\mathrm{CO}_{2} \quad(80: 20)$ and $\mathrm{N}_{2}+\mathrm{CO}_{2} \quad(80: 20)$ $(200 \mathrm{kPa})$ were tested as gas phases with MJYPV medium in the presence or absence of possible alternative electron acceptors such as $0 \cdot 1 \%(\mathrm{w} / \mathrm{v}) \mathrm{NaNO}_{3}, \mathrm{Na}_{2} \mathrm{SO}_{3}, \mathrm{NaNO}_{2}$ or $\mathrm{Na}_{2} \mathrm{~S}_{2} \mathrm{O}_{3}$ or $3 \%(\mathrm{w} / \mathrm{v}) \mathrm{S}^{0}$. To ensure anaerobic growth conditions, a $10 \%$ (w/v) $\mathrm{Na}_{2} \mathrm{~S} .9 \mathrm{H}_{2} \mathrm{O}$ solution ( $\mathrm{pH} 7 \cdot 5$, adjusted with $\mathrm{H}_{2} \mathrm{SO}_{4}$ and separately autoclaved) was added to the medium to a final concentration of $0.05 \%(\mathrm{w} / \mathrm{v})$. Autotrophic growth was determined with air using MJ synthetic sea water containing $1 \%(\mathrm{v} / \mathrm{v})$ vitamin solution, supplemented with a possible electron donor $\left(0 \cdot 1 \% \mathrm{Na}_{2} \mathrm{~S}_{2} \mathrm{O}_{3}\right.$, tetrathionate, $\mathrm{NaNO}_{2}$ or $\mathrm{Na}_{2} \mathrm{SO}_{3}$ or $3 \% \mathrm{~S}^{0}$ ) and $0 \cdot 2 \%(\mathrm{w} / \mathrm{v}) \mathrm{NaHCO}_{3}$ as a carbon source.

Measurement of growth. Growth of the isolate was determined by measuring turbidity at $600 \mathrm{~nm}$ using a spectrophotometer (UV160A; Shimadzu) and by direct cell counts after staining with $4^{\prime}$, 6-diamidino-2-phenylindole (DAPI) (Porter \& Feig, 1980) using a Nikon Eclipse E800 microscope equipped with a colour chilled 3 CCD camera system (C5810; Hamamatsu Hokutonikusu). Duplicate cultures were grown in cotton-plugged $300 \mathrm{ml}$ Erlenmeyer flasks containing $100 \mathrm{ml}$ medium in an air-batch rotary shaker (RGS32.TT; Sanki Seiki) and were shaken at 100 r.p.m. in all cases. Temperatures were measured inside control flasks alongside the cultures; temperatures were stable during the cultivation period. Growth at various $\mathrm{pH}$ values and $\mathrm{NaCl}$ concentrations was determined at $67.5^{\circ} \mathrm{C}$ and the growth conditions for all other cultivation tests were $67 \cdot 5^{\circ} \mathrm{C}$ and $\mathrm{pH} 7 \cdot 0$, unless otherwise noted.

Biochemical properties. Catalase activity was determined by the formation of oxygen bubbles with $3 \%$ hydrogen peroxide solution. Oxidase activity was determined by the oxidation of $1 \%(\mathrm{w} / \mathrm{v})$ TMPD (N,N,N', $\mathrm{N}^{\prime}$-tetramethyl-p-phenylenediamine dihydrochloride) solution on filter paper at room temperature using $T$. thermophilus $\mathrm{HB}^{\mathrm{T}}$ (=ATCC $27634^{\mathrm{T}}$ ) as a positive control. Gelatin, starch and casein hydrolysis were examined as described previously (Marteinsson et al., 1995).

Light and electron microscopy. Cells were routinely observed with a differential interference microscope (UFX; Nikon). For observation by TEM, cells were fixed with $1 \%(\mathrm{v} / \mathrm{v})$ glutaraldehyde in $0 \cdot 1 \mathrm{M} \mathrm{Na}_{2} \mathrm{HPO}_{4} / \mathrm{KH}_{2} \mathrm{PO}_{4}(\mathrm{pH} 7 \cdot 2)$ buffer and post-fixed with $1 \%$ $(\mathrm{v} / \mathrm{v}) \mathrm{OsO}_{4}$. The fixed cells were then dehydrated with an increasing concentration series of ethanol and embedded in epoxy resin. Ultrathin sections were stained with uranyl acetate and lead acetate and examined under an $\mathrm{H}-700 \mathrm{H} \mathrm{EM} \mathrm{(Hitachi)} \mathrm{at} \mathrm{an} \mathrm{accelerating}$ voltage of $100 \mathrm{kV}$. Negative staining of cells for EM was achieved with $2 \%(\mathrm{v} / \mathrm{v})$ phosphotungstic acid.

Organic substrates for growth. In an attempt to find organic substrates that could support or stimulate growth of the isolates, various organic substrates were tested instead of both yeast extract and tryptone in MJYPV medium. Each of the following substrates was added alone or with $0.01 \%$ yeast extract at concentrations of 0.02 and $0.2 \%(\mathrm{w} / \mathrm{v})$ : L-arginine, L-asparagine, L-aspartate, L-glutamate, L-phenylalanine, L-proline, L-serine, L-valine, Casamino acids, gelatin, D-(-)-fructose, D-(+)-glucose, galactose, myo-inositol, D-sorbitol, D-(+)-xylose, D- $(+)$-cellobiose, lactose, maltose, D-(+)-trehalose, sucrose, chitin, starch, sodium acetate, citrate, glycerol, L-malate, sodium pyruvate, casein, yeast extract and tryptone peptone (Difco). 
The cells were pre-cultured in each medium prior to inoculation of the same medium. These tests were performed at temperatures of 62.5 and $67.5{ }^{\circ} \mathrm{C}$ in shake flasks and run in duplicate.

Cellular fatty acid composition and respiratory quinone analyses. The cellular fatty acid composition was analysed using cells grown in MJYPV medium at $67.5^{\circ} \mathrm{C}$ at the late-exponential growth phase. Cellular fatty acid composition and respiratory quinone analyses were performed at NCIMB Japan Corporation, Shizuoka, Japan. Quinones were extracted from freeze-dried cells with chloroform/methanol $(2: 1, \mathrm{v} / \mathrm{v})$ and acetone and purified by TLC. They were separated with HPLC equipped with a Shim-pack VP-ODS column (Shimadzu) for identification (Tamaoka et al., 1983).

Fatty acids were converted to methyl esters by treatment with anhydrous methanolic $\mathrm{HCl}$. Fatty acid methyl esters were analysed by GC using a non-polar capillary column and flame-ionization detection.

Isolation and base composition of DNA. Genomic DNA of strain $\mathrm{Tl}^{\mathrm{T}}$ was prepared as described by Lauerer et al. (1986). The $\mathrm{G}+\mathrm{C}$ content of the genomic DNA was determined by direct analysis of deoxyribonucleotides using HPLC with a DNA-GC kit (Yamasa Shouyu) after digestion of the DNA with nuclease P1 (Tamaoka \& Komagata, 1984).

Amplification of 16S rRNA gene and sequence determination. The $16 \mathrm{~S}$ rRNA gene was amplified by PCR using Eubac 27F and 1492R primers (DeLong, 1992). The $1.5 \mathrm{~kb}$ PCR product was sequenced directly by the dideoxynucleotide chain-termination method using an ABI 373A automated DNA sequencer (Applied Biosystems). The almost complete sequence (1493 bp) of the $16 \mathrm{~S}$ rDNA of strain $\mathrm{T1}^{\mathrm{T}}$ was aligned manually with a subset of 16S rDNA sequences obtained from the DNA Database of Japan (DDBJ) and the Ribosomal Database Project II (RDP-II) (Maidak et al., 2001) using CLUSTAL X (Thompson et al., 1997). Phylogenetic analyses were restricted to nucleotide positions that could be aligned unambiguously in all sequences (Takai \& Horikoshi, 1999; Takai \& Sako, 1999). Neighbour-joining analysis (Saitou \& Nei, 1987) of 1265 homologous positions was accomplished using CLUSTAL X. Bootstrap analysis was used to provide confidence estimates for phylogenetic tree topologies.

\section{RESULTS AND DISCUSSION}

\section{Enrichment and purification}

Enrichment cultures in MJYPV medium were from the subsample obtained from the $1-3 \mathrm{~mm}$ surface layer of the chimney structure at 70 and $85{ }^{\circ} \mathrm{C}$. The enrichment cultures grown at $70{ }^{\circ} \mathrm{C}$ consisted of slightly motile, long rod-shaped cells, whereas the cultures at $85^{\circ} \mathrm{C}$ were highly motile coccoids. A culture containing rod-shaped cells was streaked onto an MJYPV plate hardened with $0.5 \%$ gelrite gellan gum at $70{ }^{\circ} \mathrm{C}$. In the first plate grown at $70{ }^{\circ} \mathrm{C}$, most of the colonies were large $(2 \cdot 5-3.0 \mathrm{~mm}$ in diameter), white and rough, although several small $(<1.5 \mathrm{~mm}$ in diameter), light-yellow colonies were observed. A single large, white colony was purified and designated strain $\mathrm{T1}^{\mathrm{T}} \quad(=\mathrm{JCM}$ $11576^{\mathrm{T}}=\mathrm{DSM} 14884^{\mathrm{T}}$ ) and investigated in detail. The partial sequence ( $862 \mathrm{bp}$ ) of the $16 \mathrm{~S}$ rDNA of a strain purified from a small, yellow colony was found to be closely related (98.4\%) to that of Rhodothermus marinus. Purity was confirmed routinely by microscopic examination and by repeated partial sequencing of the 16S rRNA gene using several PCR primers.

\section{Morphology}

Cells of strain $\mathrm{T}^{\mathrm{T}}$ were Gram-negative rods, about 7.5-9.4 $\mu \mathrm{m}$ long and $0 \cdot 9-1 \cdot 0 \mu \mathrm{m}$ wide in the exponential growth phase (Fig. 1a). In the stationary growth phase, the cells tended to form filaments. 'Rotund bodies', occasionally observed in many Thermus strains (Brock \& Edwards, 1970), were never observed microscopically. EMs of thin sections showed that the isolate had a cell wall structure typical of Gram-negative bacteria. The cells have an envelope consisting of a cytoplasmic membrane with a simple outline and a cell wall with an inner, electron-dense thin layer, presumably representing the peptidoglycan (Fig. 1b).

\section{Growth parameters}

The isolate grew only under strictly aerobic culture conditions and was an obligate heterotroph; it did not grow under any of the anaerobic or autotrophic culture conditions
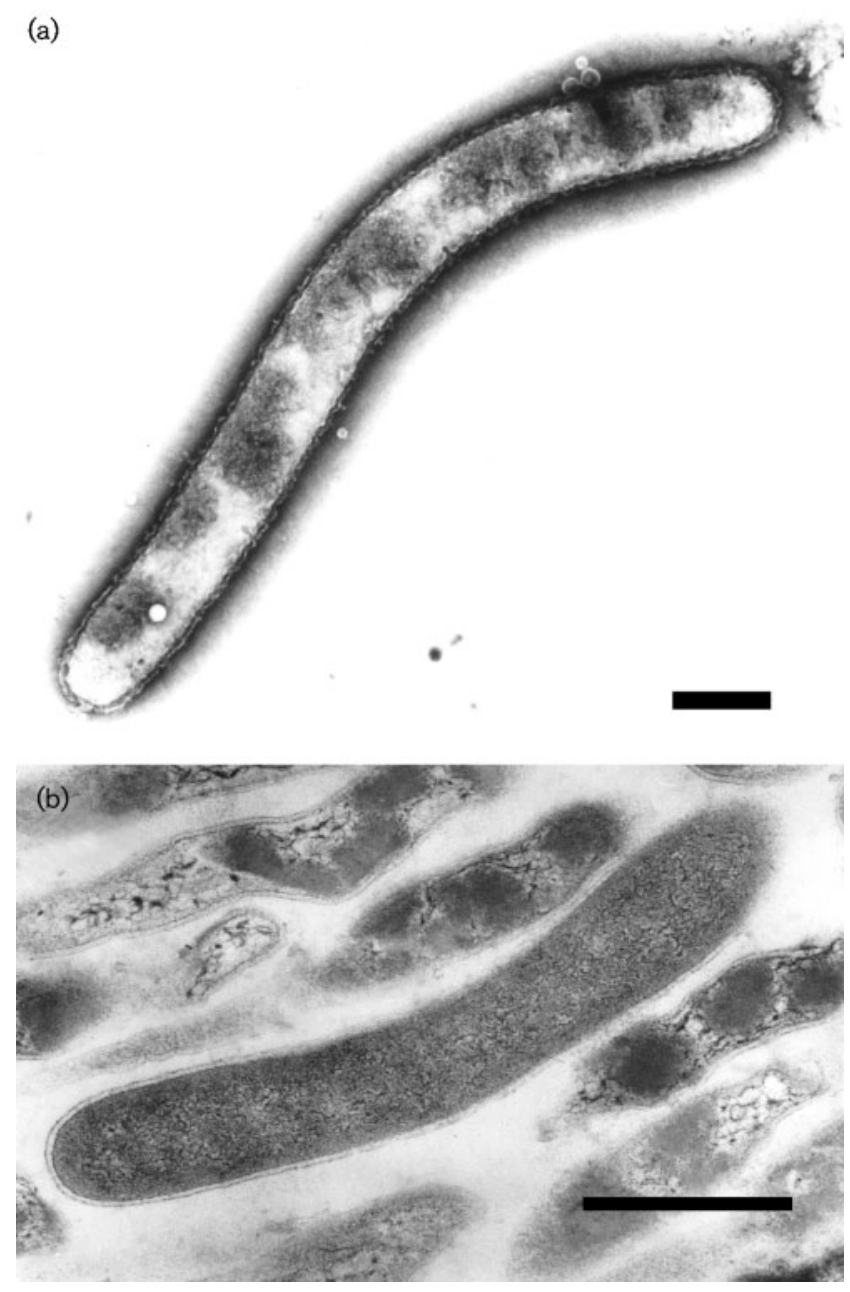

Fig. 1. TEM of a negatively stained cell (a) and thin-section (b) of strain $\mathrm{T}^{\top}{ }^{\mathrm{T}}$ in the exponential growth phase. Bars, $1 \mu \mathrm{m}$. 
tested. Unlike members of the genus Thermus, the isolate was catalase- and cytochrome oxidase-negative and did not hydrolyse gelatin, starch or casein.

The isolate grew at temperatures of about $50 \cdot 0-72 \cdot 5{ }^{\circ} \mathrm{C}$, showing optimum growth at $67 \cdot 5^{\circ} \mathrm{C}$; the generation time at $67.5^{\circ} \mathrm{C}$ was about $30 \mathrm{~min}$. No growth was observed at 75 or $45^{\circ} \mathrm{C}$ (Fig. 2a). Growth of the isolate at $67.5{ }^{\circ} \mathrm{C}$ occurred between $\mathrm{pH} 6.25$ and $7 \cdot 75$, with optimum growth at about $\mathrm{pH} 7 \cdot 0$. No growth was detected below $\mathrm{pH} 6 \cdot 25$ or above $\mathrm{pH} 7 \cdot 75$ (Fig. $2 \mathrm{~b}$ ). The isolate absolutely required $\mathrm{NaCl}$ for growth and was able to grow in $0 \cdot 5-4 \cdot 5 \% \mathrm{NaCl}$. Optimum growth was detected at around $3 \% \mathrm{NaCl}$ at $67.5{ }^{\circ} \mathrm{C}$. No growth was observed below $0.5 \%$ or above $5 \% \mathrm{NaCl}$ (Fig. 2c).

\section{Nutrition}

The isolate was able to utilize complex organic substrates such as yeast extract, Casamino acids and tryptone as sole energy and carbon sources. Furthermore, acetate $(0 \cdot 2 \%)$, pyruvate $(0.02 \%)$, glutamate $(0.2 \%)$, proline $(0.2 \%)$ and serine $(0.2 \%)$ improved the growth yield of the isolate in the presence of $0.01 \%$ yeast extract. However, none of the sugars used in this study stimulated growth at $67.5^{\circ} \mathrm{C}$; $0.2 \%$ each of cellobiose, trehalose and sucrose stimulated growth at $62.5{ }^{\circ} \mathrm{C}$ in the presence of $0.01 \%$ yeast extract.

\section{Fatty acid, quinone and DNA base composition}

When the isolate was grown at $67.5{ }^{\circ} \mathrm{C}$, the major cellular fatty acids were iso- $\mathrm{C}_{15: 0}(40 \cdot 4 \%)$, iso- $\mathrm{C}_{17: 0}(28.5 \%)$, $\mathrm{C}_{16: 0}(12 \cdot 9 \%)$, anteiso- $\mathrm{C}_{15: 0}(6.0 \%)$, anteiso- $\mathrm{C}_{17: 0}$ $(5 \cdot 4 \%)$, iso- $\mathrm{C}_{16: 0}(2 \cdot 8 \%)$ and iso $3-\mathrm{OH} \mathrm{C} \mathrm{C}_{11: 0}(1 \cdot 0 \%)$. Menaquinone- 8 was the major respiratory quinone. This fatty acid and respiratory quinone composition was similar to those of members of the genus Thermus, as described previously (Hensel et al., 1986; Prado et al., 1988). However, the presence of iso $3-\mathrm{OH} \mathrm{C}_{11: 0}$ in the fatty acid composition of the isolate distinguished it from Thermus species.

The $\mathrm{G}+\mathrm{C}$ content of the genomic DNA of strain $\mathrm{T1}^{\mathrm{T}}$ was $68.6 \mathrm{~mol} \%$. This value is very similar to those of members of the genus Thermus (Duffield \& Cossar, 1995).

\section{Phylogenetic analyses}

The almost complete 16S rRNA gene sequence (1493 bp) from strain $\mathrm{T}^{\mathrm{T}}$ was determined and was most closely related to sequences from members of the genus Thermus, such as Thermus igniterrae RF-4 $4^{\mathrm{T}}(88.6 \%)$ (Chung et al., 2000 ) and Thermus oshimai $\mathrm{SPS}_{1} 7^{\mathrm{T}}(88 \cdot 6 \%)$ (Williams et al., 1996). This low phylogenetic relatedness is below the common index of $16 \mathrm{~S}$ rDNA sequence similarity for differentiation of micro-organisms at the genus level (90$96 \%$ ) (Gillis et al., 2001), although most of physiological
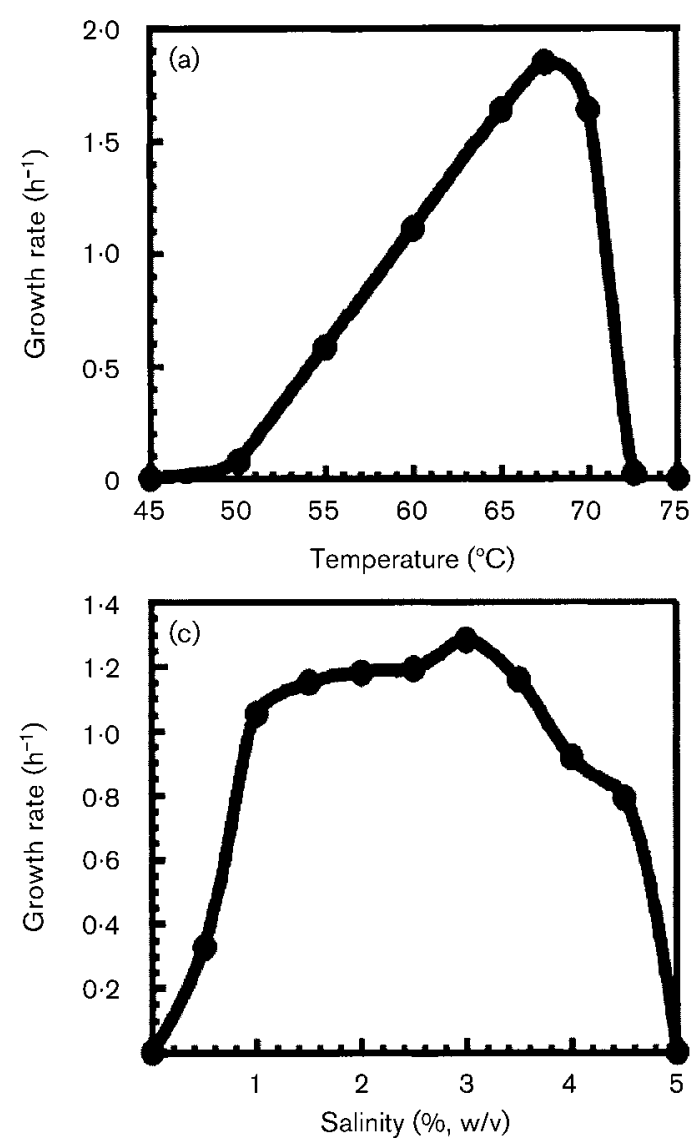

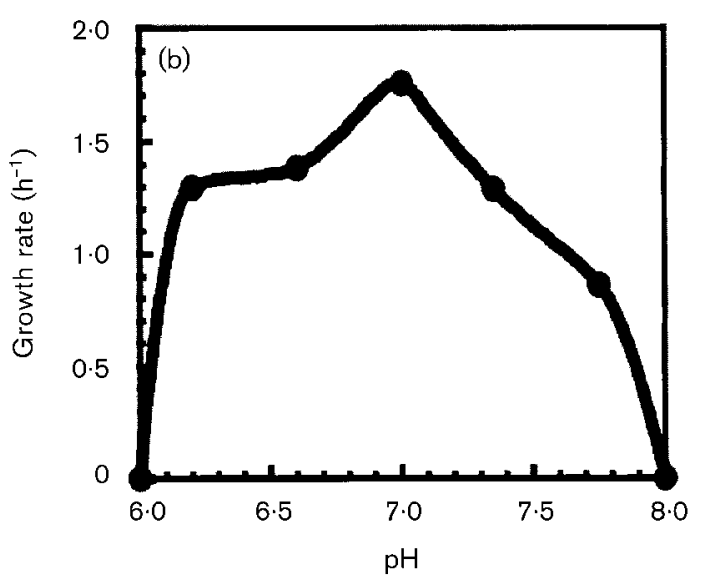

Fig. 2. Effect of temperature (a), $\mathrm{pH}$ (b) and $\mathrm{NaCl}$ concentration (c) on growth of strain $\mathrm{T}^{\top}{ }^{\top}$. Growth curves at different temperatures were determined in MJYPV medium at $\mathrm{pH} 7 \cdot 0$. The effects of different $\mathrm{pH}$ values and $\mathrm{NaCl}$ concentrations on growth were determined in the same medium at $67.5^{\circ} \mathrm{C}$. 
and chemotaxonomic features (temperature and $\mathrm{pH}$ ranges for growth, $\mathrm{G}+\mathrm{C}$ content of the genomic DNA, major fatty acid and quinone compositions) of strain $\mathrm{T}^{\mathrm{T}}$ were similar to those displayed by members of the genus Thermus. To determine the phylogenetic position of the isolate, evolutionary distances based on 16S rRNA gene sequences of representative members of the Bacteria were calculated and a phylogenetic tree was constructed using the neighbourjoining method (Fig. 3). In the phylogenetic tree, the isolate was on a distinct branch deeply separated from a cluster of the branches of Thermus strains, which also supported phylogenetic differentiation of the isolate from members of the genus Thermus.

\section{Ecological niche}

A number of heterotrophic thermophiles, decomposers of the organic material from thermophilic microbial communities in deep-sea hydrothermal vent environments, such as members of the Thermococcales and Thermotogales, have been isolated and detected (Gonzales et al., 1995; Harmsen et al., 1997; Takai et al., 2000, 2001; Takai \& Horikoshi, 2000; Holden et al., 2001; Wery et al., 2001). Most of these thermophilic bacteria and archaea are strict anaerobes with fermentative metabolisms, and several strains within the orders Archaeoglobales (Burggraf et al., 1990; Huber et al., 1997) and Desulfurococcales (Jannasch et al., 1988; Pley et al., 1991; Blöchl et al., 1997) have anaerobic respiratory metabolisms using sulfate, sulfite and elemental sulfur as electron acceptors. Considering the successful retrieval of strain $\mathrm{T} 1^{\mathrm{T}}$ from the surface zone of the chimney structure and the strict $\mathrm{O}_{2}$-dependence of its metabolism, active populations of this strain might be distributed in relatively oxidative microhabitats such as the surface area of chimney

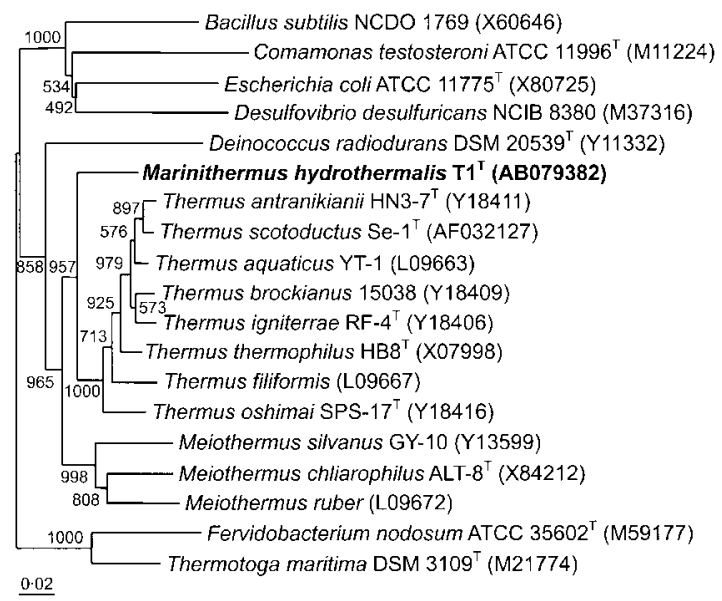

Fig. 3. Phylogenetic tree showing the positions of representative members of the Bacteria inferred from 16S rDNA sequence data. Numbers are bootstrap values for branches (based on 1000 replicates). Bar, 0.02 substitutions per nucleotide. EMBL/GenBank/DDBJ database accession numbers are shown in parentheses. structures in deep-sea hydrothermal vent environments. Recent culture-independent molecular analyses have indicated the prevalence of putative mesophilic e-Proteobacteria in the surface area of chimney structures and sulfide materials (Moyer et al., 1994, 1995; Reysenbach et al., 2000b). The finding of strictly aerobic, heterotrophic thermophiles such as strain $\mathrm{Tl}^{\mathrm{T}}$ and Rhodothermus strains from the surface microhabitats of the chimney structure may provide a new insight into the ecological significance of the aerobic, thermophilic decomposers in the circulation of organic compounds in deep-sea hydrothermal vent ecosystems.

The isolate represents a distinct lineage within the family Thermaceae. Many strains of Thermus and Meiothermus have been isolated from terrestrial geothermal environments, although some strains, such as T. thermophilus Gy1211, have been obtained from shallow and deep-sea hydrothermal vent environments (Hudson et al., 1986; Kristjánsson et al., 1986; Hjörleifsdóttir et al., 1989; Manaia \& da Costa, 1991; Marteinsson et al., 1999). A distinctive physiological feature commonly displayed by all Thermus strains, including marine isolates, is that they do not show an absolute requirement for $\mathrm{NaCl}$ for growth. Strain $\mathrm{T1}^{\mathrm{T}}$ is the first isolate within the phylum Thermus/Deinococcus that grows optimally under a salinity equivalent to that of sea water and has an absolute requirement for $\mathrm{NaCl}$ for growth. On the basis of these results, a new genus, Marinithermus gen. nov., is proposed. The type species is Marinithermus hydrothermalis gen. nov., sp. nov., of which the type strain is strain $\mathrm{Tl}^{\mathrm{T}}\left(=\mathrm{JCM} 11576^{\mathrm{T}}=\mathrm{DSM} 14884^{\mathrm{T}}\right)$.

\section{Description of Marinithermus gen. nov.}

Marinithermus (ma.ri.ni.ther'mus. L. adj. marinus of the sea; Gr. adj. thermos hot; N.L. n. Marinithermus an organism living in marine hot places).

Rod-shaped bacterium, Gram-negative, with branched chain fatty acids and menaquinone-8. Thermophilic. Growth suited to the $\mathrm{pH}$ and salinity of sea water; able to grow at $55-70{ }^{\circ} \mathrm{C}$, $\mathrm{pH} 6 \cdot 2-7 \cdot 7$ and $1 \cdot 0-4 \cdot 5 \% \mathrm{NaCl}$. Aerobic, heterotrophic, able to utilize organic complex substrates, amino acids, carboxylic acids and sugars. The $\mathrm{G}+\mathrm{C}$ content is approximately $68 \mathrm{~mol} \%$. $16 \mathrm{~S}$ rDNA sequence comparison locates Marinithermus in a novel lineage deeply branched prior to the divergence of the genus Thermus. The type species is Marinithermus hydrothermalis.

\section{Description of Marinithermus hydrothermalis sp. nov.}

Marinithermus hydrothermalis (hy.dro.ther.ma' lis. N.L. masc. adj. hydrothermalis pertaining to a hydrothermal vent).

Cells are Gram-negative, non-motile, straight rods, 7·5$9 \cdot 4 \times 0 \cdot 9-1 \cdot 0 \mu \mathrm{m}$, that occur in pairs or are filamentous under optimal conditions. Colonies are whitish and 2.5$3.0 \mathrm{~mm}$ in diameter. Aerobic, thermophilic, neutrophilic heterotroph. Growth occurs at temperatures of $50 \cdot 0$ $72.5{ }^{\circ} \mathrm{C}$ (optimum $67 \cdot 5^{\circ} \mathrm{C}$ ), at $\mathrm{pH} 6 \cdot 25-7 \cdot 75$ (optimum 
$\mathrm{pH} 7 \cdot 0$ ) and in the presence of $0 \cdot 5-4 \cdot 5 \% \mathrm{NaCl}$ (optimum $3 \% \mathrm{NaCl}$ ). Generation time under optimal conditions is about $30 \mathrm{~min}$. Cytochrome oxidase- and catalase-negative. The major cellular fatty acid components are iso- $\mathrm{C}_{15: 0}$ $(40.4 \%)$, iso-C $\mathrm{C}_{17: 0}(28.5 \%), \mathrm{C}_{16: 0}(12.9 \%)$, anteiso$\mathrm{C}_{15: 0}(6 \cdot 0 \%)$, anteiso- $\mathrm{C}_{17: 0}(5 \cdot 4 \%)$, iso- $\mathrm{C}_{16: 0}(2 \cdot 8 \%)$ and iso $3-\mathrm{OH} \mathrm{C}_{11: 0}(1.0 \%)$. The major quinone is menaquinone-8. Growth occurs on complex organic substrates such as yeast extract and tryptone peptone. The DNA base composition of the type strain, strain $\mathrm{T}^{\mathrm{T}}$ (=JCM $\left.11576^{\mathrm{T}}=\mathrm{DSM} 14884^{\mathrm{T}}\right)$, is $68 \cdot 6 \mathrm{~mol} \%$. Isolated from a deep-sea hydrothermal vent chimney at Suiyo Seamount in the Izu-Bonin Arc, Japan $\left(28^{\circ} 34 \cdot 287^{\prime} \mathrm{N}, 140^{\circ} 38 \cdot 663^{\prime} \mathrm{E}\right.$; depth $1385 \mathrm{~m}$ ).

\section{ACKNOWLEDGEMENTS}

We would like to thank for Dr Fumio Inagaki, Japan Marine Science \& Technology Center (JAMSTEC), Yokosuka, Japan, for his advice and suggestions. We also thank the captain and the crew of Natsushima, the mother ship of Shinkai 2000. We are grateful to Mr Takahiko Higasa, Graduate School of Agriculture, Kyoto University, Japan, for the electron micrographs. This work was partially supported by a Grant-in-Aid for Scientific Research (no. 12460093) from the Ministry of Education, Culture, Sports, Science and Technology of Japan.

\section{REFERENCES}

Balch, W. E., Fox, G. E., Magrum, L. J., Woese, C. R. \& Wolfe, R. S. (1979). Methanogens: re-evaluation of a unique biological group. Microbiol Rev 43, 260-296.

Blöchl, E., Rachel, R., Burggraf, S., Hafenbradl, D., Jannasch, H. W. \& Stetter, K. O. (1997). Pyrolobus fumarii, gen. and sp. nov., represents a novel group of archaea, extending the upper temperature limit for life to $113{ }^{\circ} \mathrm{C}$. Extremophiles 1, 14-21.

Brock, T. D. \& Boylen, K. L. (1973). Presence of thermophilic bacteria in laundry and domestic hot-water heaters. Appl Microbiol 25, 72-76.

Brock, T. D. \& Edwards, M. R. (1970). Fine structure of Thermus aquaticus, an extreme thermophile. J Bacteriol 104, 509-517.

Brock, T. D. \& Freeze, H. (1969). Thermus aquaticus gen. n., and sp. n., a nonsporulating extreme thermophile. J Bacteriol 98, 289297.

Brock, T. D., Brock, K. M., Belly, R. T. \& Weiss, R. L. (1972). Sulfolobus: a new genus of sulfur-oxidizing bacteria living at low $\mathrm{pH}$ and high temperature. Arch Mikrobiol 84, 54-68.

Burggraf, S., Jannasch, H. W., Nicolaus, B. \& Stetter, K. O. (1990). Archaeoglobus profundus, sp. nov., represents a new species within the sulfate-reducing archaebacteria. Syst Appl Microbiol 13, 24-28.

Chung, A. P., Rainey, F. A., Valente, M., Nobre, M. F. \& da Costa, M. S. (2000). Thermus igniterrae sp. nov. and Thermus antranikianii sp. nov., two new species from Iceland. Int J Syst Evol Microbiol 50, 209-217.

DeLong, E. F. (1992). Archaea in coastal marine environments. Proc Natl Acad Sci U S A 89, 5685-5689.

Duffield, M. \& Cossar, D. (1995). Enzymes of Thermus and their properties. In Thermus Species, pp. 93-141. Edited by R. Sharp \& R. Williams. New York: Plenum Press.
Gillis, M., Vandamme, P., De Vos, P., Swings, J. \& Kersters, K. (2001). Polyphasic taxonomy. In Bergey's Manual of Systematic Bacteriology, 2nd edn, pp. 43-48. Edited by D. R. Boone, R. W. Castenholz \& G. M. Garrity. New York: Springer.

Gonzales, J. M., Kato, C. \& Horikoshi, K. (1995). Thermococcus peptonophilus sp. nov., a fast-growing, extremely thermophilic archaebacterium isolated from deep-sea hydrothermal vents. Arch Microbiol 164, 159-164.

Grogan, D., Palm, P. \& Zillig, W. (1990). Isolate B12, which harbours a virus-like element, represents a new species of the archaebacterial genus Sulfolobus, Sulfolobus shibatae, sp. nov. Arch Microbiol 154, 594-599.

Harmsen, H. J. M., Prieur, D. \& Jeanthon, C. (1997). Distribution of microorganisms in deep-sea hydrothermal vent chimneys investigated by whole-cell hybridization and enrichment culture of thermophilic subpopulations. Appl Environ Microbiol 63, 2876-2883.

Hensel, R., Demharter, W., Kandler, O., Kroppenstedt, R. M. \& Stackebrandt, E. (1986). Chemotaxonomic and molecular-genetic studies of the genus Thermus: evidence for a phylogenetic relationship of Thermus aquaticus and Thermus ruber to the genus Deinococcus. Int J Syst Bacteriol 36, 444-453.

Hjörleifsdóttir, S., Kristjánsson, J. K. \& Alfredsson, G. A. (1989). Thermophilic organisms in submarine freshwater hot springs in Iceland. In Microbiology of Extreme Environments and its Potential for Biotechnology, pp. 109-112. Edited by M. S. da Costa, J. C. Duarte \& R. A. D. Williams. London: Elsevier.

Holden, J. F., Takai, K., Summit, M., Bolton, S., Zyskowski, J. \& Baross, J. A. (2001). Diversity among three novel groups of hyperthermophilic deep-sea Thermococcus species from three sites in the northeastern Pacific Ocean. FEMS Microbiol Ecol 36, 51-60.

Huber, R., Wilharm, T., Huber, D. \& 7 other authors (1992). Aquifex pyrophilus gen. nov., sp. nov., represents a novel group of marine hyperthermophilic hydrogen-oxidizing bacteria. Syst Appl Microbiol 15, 340-351.

Huber, H., Jannasch, H. W., Rachel, R., Fuchs, T. \& Stetter, K. O. (1997). Archaeoglobus veneficus sp. nov., a novel facultative chemolithoautotrophic hyperthermophilic sulfite reducer, isolated from abyssal black smoker. Syst Appl Microbiol 20, 374-380.

Hudson, J. A., Morgan, H. W. \& Daniel, R. M. (1986). A numerical classification of some Thermus isolates. J Gen Microbiol 132, 531540 .

Jannasch, H. W., Wirsen, C. O., Molyneaux, S. J. \& Langworthy, T. A. (1988). Extremely thermophilic fermentative archaebacteria of the genus Desulfurococcus from deep-sea hydrothermal vents. Appl Environ Microbiol 54, 1203-1209.

Kieft, T. L., Fredrickson, J. K., Onstott, T. C. \& 7 other authors (1999). Dissimilatory reduction of $\mathrm{Fe}(\mathrm{III})$ and other electron acceptors by a Thermus isolate. Appl Environ Microbiol 65, 12141221.

Kristjánsson, J. K. \& Alfredsson, G. A. (1983). Distribution of Thermus spp. in Icelandic hot springs and a thermal gradient. Appl Environ Microbiol 45, 1785-1789.

Kristjánsson, J. K., Hreggvidsson, G. O. \& Alfredsson, G. A. (1986). Isolation of halotolerant Thermus spp. from submarine hot springs in Iceland. Appl Environ Microbiol 52, 1313-1316.

Lauerer, G., Kristjánsson, J. K., Langworthy, T. A., König, H. \& Stetter, K. O. (1986). Methanothermus sociabilis sp. nov., a second species within the Methanothermaceae growing at $97^{\circ} \mathrm{C}$. Syst Appl Microbiol 8, 100-105.

Maidak, B. L., Cole, J. R., Lilburn, T. G. \& 7 other authors (2001). The RDP-II (Ribosomal Database Project). Nucleic Acids Res 29, 173-174. 
Manaia, C. M. \& da Costa, M. S. (1991). Characterization of halotolerant Thermus isolates from shallow marine hot springs on S. Miguel, Azores. J Gen Microbiol 137, 2643-2648.

Marteinsson, V. T., Birrien, J. L., Kristjánsson, J. K. \& Prieur, D. (1995). First isolation of thermophilic aerobic nonsporulating heterotrophic bacteria from deep-sea hydrothermal vents. FEMS Microbiol Ecol 18, 163-174.

Marteinsson, V. T., Birrien, J. L., Raguénès, G., da Costa, M. S. \& Prieur, D. (1999). Isolation and characterization of Thermus thermophilus Gy1211 from a deep-sea hydrothermal vent. Extremophiles 3, 247-251.

Moyer, C. L., Dobbs, F. C. \& Karl, D. M. (1994). Estimation of diversity and community structure through restriction fragment length polymorphism distribution analysis of bacterial 16S rRNA genes from a microbial mat at an active, hydrothermal vent system, Loihi Seamount, Hawaii. Appl Environ Microbiol 60, 871-879.

Moyer, C. L., Dobbs, F. C. \& Karl, D. M. (1995). Phylogenetic diversity of the bacterial community from a microbial mat at an active, hydrothermal vent system, Loihi Seamount, Hawaii. Appl Environ Microbiol 61, 1555-1562.

Pask-Hughes, R. A. \& Williams, R. A. D. (1975). Extremely thermophilic Gram-negative bacteria from hot tap water. $J$ Gen Microbiol 88, 321-328.

Pley, U., Schipka, J., Gambacorta, A., Jannasch, H. W., Fricke, H., Rachel, R. \& Stetter, K. O. (1991). Pyrodictium abyssi, sp. nov., represents a novel heterotrophic marine archaeal hyperthermophile growing at $110^{\circ} \mathrm{C}$. Syst Appl Microbiol 14, 245-253.

Porter, K. G. \& Feig, Y. S. (1980). The use of DAPI for identifying and counting microflora. Limnol Oceanogr 25, 943-948.

Prado, A., da Costa, M. S. \& Madeira, V. M. C. (1988). Effect of growth temperature on the lipid composition of two strains of Thermus sp. J Gen Microbiol 134, 1653-1660.

Reysenbach, A.-L., Banta, A. B., Boone, D. R., Cary, S. C. \& Luther, G. W. (2000a). Microbial essentials at hydrothermal vents. Nature 404, 835.

Reysenbach, A.-L., Longnecker, K. \& Kirshtein, J. (2000b). Novel bacterial and archaeal lineages from an in situ growth chamber deployed at a Mid-Atlantic Ridge hydrothermal vent. Appl Environ Microbiol 66, 3798-3806.

Saitou, N. \& Nei, M. (1987). The neighbor-joining method: a new method for reconstructing phylogenetic trees. Mol Biol Evol 4, 406425.

Sako, Y., Nomura, N., Uchida, A., Ishida, Y., Morii, H., Koga, Y., Hoaki, T. \& Maruyama, T. (1996a). Aeropyrum pernix gen. nov., sp. nov., a novel aerobic hyperthermophilic archaeon growing at temperatures up to $100{ }^{\circ} \mathrm{C}$. Int J Syst Bacteriol 46, 1070-1077.

Sako, Y., Takai, K., Ishida, Y., Uchida, A. \& Katayama, Y. (1996b). Rhodothermus obamensis sp. nov., a modern lineage of extremely thermophilic marine bacteria. Int J Syst Bacteriol 46, 1099-1104.
Sako, Y., Nunoura, T. \& Uchida, A. (2001). Pyrobaculum oguniense sp. nov., a novel facultatively aerobic and hyperthermophilic archaeon growing at up to $97^{\circ} \mathrm{C}$. Int J Syst Evol Microbiol 51, 303-309.

Sharp, R., Cossar, D. \& Williams, R. (1995). Physiology and metabolism of Thermus. In Thermus Species, pp. 67-91. Edited by R. Sharp \& R. Williams. New York: Plenum Press.

Skirnisdottir, S., Hreggvidsson, G. O., Holst, O. \& Kristjánsson, J. K. (2001). Isolation and characterization of a mixotrophic sulfuroxidizing Thermus scotoductus. Extremophiles 5, 45-51.

Takai, K. \& Horikoshi, K. (1999). Genetic diversity of archaea in deep-sea hydrothermal vent environments. Genetics 152, 1285-1297.

Takai, K. \& Horikoshi, K. (2000). Thermosipho japonicus sp. nov., an extremely thermophilic bacterium isolated from a deep-sea hydrothermal vent in Japan. Extremophiles 4, 9-17.

Takai, K. \& Sako, Y. (1999). A molecular view of archaeal diversity in marine and terrestrial hot water environments. FEMS Microbiol Ecol 28, 177-188.

Takai, K., Sugai, A., Itoh, T. \& Horikoshi, K. (2000). Palaeococcus ferrophilus gen. nov., sp. nov., a barophilic, hyperthermophilic archaeon from a deep-sea hydrothermal vent chimney. Int J Syst Evol Microbiol 50, 489-500.

Takai, K., Komatsu, T., Inagaki, F. \& Horikoshi, K. (2001). Distribution of archaea in a black smoker chimney structure. Appl Environ Microbiol 67, 3618-3629.

Tamaoka, J. \& Komagata, K. (1984). Determination of DNA base composition by reversed-phase high-performance liquid chromatography. FEMS Microbiol Lett 25, 125-128.

Tamaoka, J., Katayama-Fujiwara, Y. \& Kuraishi, H. (1983). Analysis of bacterial menaquinone mixtures by high-performance liquid chromatography. J Appl Bacteriol 54, 31-36.

Thompson, J. D., Gibson, T. J., Plewniak, F., Jeanmougin, F. \& Higgins, D. G. (1997). The ClUSTAL $X$ windows interface: flexible strategies for multiple sequence alignment aided by quality analysis tools. Nucleic Acids Res 25, 4876-4882.

Wery, N., Lesongeur, F., Pignet, P., Derennes, V., Cambon-Bonavita, M.-A., Godfroy, A. \& Barbier, G. (2001). Marinitoga camini gen. nov., sp. nov., a rod-shaped bacterium belonging to the order Thermotogales, isolated from a deep-sea hydrothermal vent. Int J Syst Evol Microbiol 51, 495-504.

Williams, R. A. D. \& da Costa, M. S. (1992). The genus Thermus and related microorganisms. In The Prokaryotes, 2nd edn, pp. 37453753. Edited by A. Balows, H. G. Trüper, M. Dworkin, W. Harder \& K.-H. Schleifer. New York: Springer.

Williams, R. A. D., Smith, K. E., Welch, S. G. \& Micallef, J. (1996). Thermus oshimai sp. nov., isolated from hot springs in Portugal, Iceland, and the Azores, and comment on the concept of a limited geographical distribution of Thermus species. Int J Syst Bacteriol 46, 403-408. 